Agritech, 38 (2) 2018, 140-150

\title{
Sifat-Sifat Fisikokimia Pati Ubi Kayu Terfermentasi Khamir Indigenus Tapai
}

\author{
Physicochemical Properties of Cassava Starch Fermented by Indigenous-Tapai Yeasts \\ Heru Widyatmoko' ${ }^{1}$ Achmad Subagio ${ }^{2,3}$, N. Nurhayati ${ }^{1,2,3 *}$ \\ ${ }^{1}$ Program Studi Magister Bioteknologi, Universitas Jember,Jl. Kalimantan No.37 PS \\ BIOTEKNOLOGI UNEJ, Sumbersari, Jember 68121, Indonesia \\ 2Jurusan Teknologi Hasil Pertanian, Fakultas Teknologi Pertanian, Universitas Jember, \\ Jl. Kalimantan No.37 FTP UNEJ, Sumbersari, Jember 68121, Indonesia \\ ${ }^{3}$ Center for Development of Advanced Science andTechnology, Universitas Jember, \\ Jl. Kalimantan No.37 CDAST UNEJ, Sumbersari, Jember 68121, Indonesia \\ *Email: nurhayati.ftp@unej.ac.id
}

Tanggal submisi: 20 Oktober 2017; Tanggal penerimaan: 16 Januari 2018

\begin{abstract}
ABSTRAK
Tapai merupakan produk pangan ubi kayu yang terfermentasi oleh starter khamir (ragi). Di antara khamir amilolitik yang sudah diisolasi dari tapai yaitu Candida guilliermondii, C. tropicalis, Trichosporon mucoides, dan Saccharomycopsis fibuligera. Tujuan penelitian ini adalah melakukan karakterisasi sifat-sifat fisikokimia pati ubi kayu yang difermentasi oleh khamir amilolitik indigenus tapai yaitu $C$. guilliermondii, C. tropicalis, T. mucoides, dan $S$. fibuligera. Proses fermentasi pati ubi kayu dilakukan dengan menginokulasikan masing-masing isolat murni sebanyak $5 \% \mathrm{v} / \mathrm{v}\left(10^{5} \mathrm{CFU} / \mathrm{ml}\right)$ ke dalam suspensi pati ubi kayu $50 \% \mathrm{~b} / \mathrm{v}$ ( $100 \mathrm{~g}$ pati ke dalam $200 \mathrm{ml}$ akuades steril). Selanjutnya dilakukan inkubasi pada suhu $28^{\circ} \mathrm{C}$ selama 24, 48, dan 72 jam. Pati ubi kayu terfermentasi dikeringkan pada suhu 50 ${ }^{\circ} \mathrm{C}$ selama 24 jam. Karakterisasi sifat-sifat fisikokimia pati ubi kayu meliputi sifat kimia (kadar amilosa), sifat pasta (RVA), sifat termal (DSC), sifat fisik (makrostruktur granula SEM) dan gugus fungsi (FT-IR) pati ubi kayu alami maupun pati ubi kayu terfermentasi. Hasil penelitian menunjukkan bahwa selama proses fermentasi, khamir mampu tumbuh hingga mencapai $7 \log _{10} \mathrm{CFU} / \mathrm{ml}$ dan derajat keasaman mengalami penurunan mencapai $\mathrm{pH} 3,9$. Kadar amilosa pati ubi kayu terfermentasi mengalami penurunan menjadi $11,22 \%$ dari kadar amilosa pati alami $(15,85 \%)$. Sifat pasta pati ubi kayu terfermentasi khamir mengalami peningkatan pada nilai viskositas trough, breakdown, viskositas akhir, dan daya kembang. Sifat termal pati ubi kayu terfermentasi menglamai peningkatan menjadi $64,7-67^{\circ} \mathrm{C}$ untuk nilai suhu awal gelatinisasi (To), $69,1-71,2^{\circ} \mathrm{C}$ untuk suhu puncak gelatinisasi (Tp), $73,9-75^{\circ} \mathrm{C}$ untuk suhu akhir gelatinisasi

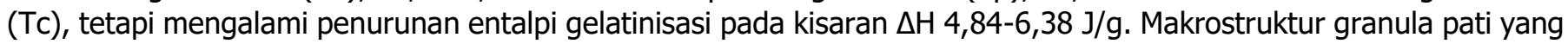
terfermentasi paling lama (72 jam) mengalami liberasi dengan bentuk granula yang tidak beraturan. Profil gugus fungsi pati ubi kayu terfermentasi oleh khamir memiliki kemiripan dengan pati ubi kayu alami yaitu memiliki spektra penyerapan tertinggi pada puncak $3291,2 \mathrm{~cm}^{-1}$ (getaran gugus ikatan O-H) dan puncak $2920 \mathrm{~cm}^{-1}$ (getaran gugus CH).
\end{abstract}

Kata kunci: Pati ubi kayu; fermentasi; khamir indigenus tapai

\begin{abstract}
Tapai is a cassava food product fermented by yeast starter ("Ragi"). Among the amylolitic yeasts that had been isolated from the tapai were Candida guilliermondii, C. tropicalis, Trichosporon mucoides, and Saccharomycopsis fibuligera. The aim of this research was to characterize the physicochemical properties of fermented cassava starch by amylolytic yeasts of indigenus tapai i.e. C. guilliermondii, $C$. tropicalis, T. mucoides, and S. fibuligera. The process of fermentation of cassava starch was done by inoculating each pure isolate by $5 \% \mathrm{v} / \mathrm{v}\left(10^{5} \mathrm{CFU} / \mathrm{ml}\right)$ into cassava starch suspension $50 \% \mathrm{~b} / \mathrm{v}$ ( $100 \mathrm{~g}$ starch into $200 \mathrm{ml}$ sterile distilled water). The incubation was carried out at $28{ }^{\circ} \mathrm{C}$ for $24 \mathrm{~h}, 48 \mathrm{~h}$, and $72 \mathrm{~h}$. The fermented cassava starch was dried at $50^{\circ} \mathrm{C}$ for $24 \mathrm{~h}$. Characterization of physicochemical properties of cassava starch included chemical properties (amylose content), paste properties (RVA), thermal properties (DSC), physical properties (SEM granule macrostructure) and functional groups (FT-IR) of unfermented (native) or fermented cassava starch. The results showed that during the fermentation process, the yeast was able to
\end{abstract}




\section{H. Widyatmoko dkk. /Agritech 38 (2) 2018 140-150}

grow up to $7 \log _{10} \mathrm{CFU} / \mathrm{ml}$ and the acidity decreased to $\mathrm{pH} 3,9$. The amylose content of fermented cassava starch decreased to $11,22 \%$ from native starch amylose content (15,85\%). The paste properties of fermented cassava starch increased at the value of trough viscosity, breakdown, final viscosity, and swelling power. The thermal properties of fermented cassava starch increased to $64,7-67{ }^{\circ} \mathrm{C}$ for the initial temperature value of gelatinization (To), 69,1-71,2 ${ }^{\circ} \mathrm{C}$ for gelatinization peak temperature (Tp), $73,9-75^{\circ} \mathrm{C}$ for the final temperature of gelatinization (Tc), but decreased

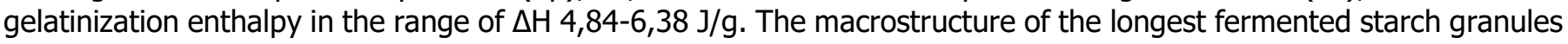
(72 hours)occurred liberation into irregular granular shapes. The profile of fermented cassava starch functional groups had a similarity with native cassava starch that had the highest absorption spectra at $3291,2 \mathrm{~cm}^{-1}$ peak (vibration of the O-H bonding group) and $2920 \mathrm{~cm}^{-1}$ peak (C-H group vibration).

Keywords: Cassava starch; fermentation; indigenous tapai yeast

\section{PENDAHULUAN}

Ubi kayu (Manihot esculenta Crants) merupakan bahan pangan yang banyak mengandung pati (starchy food). Ubi kayu sebagai komoditas pangan lokal memiliki potensi untuk menjadi produk pangan ekspor. Beberapa contoh produk olahan ubi kayu yang sudah diindustrikan diantaranya yaitu gaplek, tepung ubi kayu, tepung ubi kayu terfermentasi (MOCAF/modified cassava flour), beras ubi kayu.

Fermentasi ubi kayu juga dapat menghasilkan produk seperti tapai, peuyeum, gatot, growol, fufu dan lafun (Ogunnaike dkk., 2015). Teknologi fermentasi dapat menghasilkan produk dengan cita rasa tertentu atau bahkan mampu memperbaiki karakteristik mutu produk. Khamir banyak digunakan sebagai starter pada proses fermentasi bahan pangan berpati seperti tape, sirup kaya fruktosa (high fructose syrup/HFS), dan bir (Jimoh dkk., 2012). Khamir dalam pembuatan tapai berperan mendegradasi pati menjadi glukosa maupun senyawa aromatik seperti alkohol dan asam organik. Proses fermentasi tapai dipengaruhi oleh cara pengolahan, bahan, dan khamir yang digunakan. Kemampuan untuk mendegradasi pati tidak sama pada setiap khamir, namun beberapa khamir telah terindentifikasi mampu mendegradasi pati (Oslan dkk., 2012).

Beberapa penelitian melaporkan bahwa khamir pada tapai diantaranya yaitu $S$. cerevisiae, $C$. krusei, $C$. pelliculosa, C. utilis, C. spharearica, C. magnoliae, $R$. mucillaginosa, $R$. glutinis. Khamir pada ragi tapai yaitu Trichosporon sp, Clamydomucor sp, Candida sp, dan Saccharomyces sp (Tamang dkk., 2016). Schwan dkk., (2007) melaporkan bahwa khamir tertentu juga memiliki sifat amilolitik yang berarti khamir tersebut mampu menghasilkan enzim amilase.

Sifat fungsional pati dapat ditingkatkan atau diperbaiki melalui teknologi fermentasi. Seperti yang dilakukan oleh Subagio (2013) dalam meningkatkan sifat fungsional teknis tepung ubi kayu melalui fermentasi bakteri asam laktat sehingga dihasilkan MOCAF (modified cassava flour) yang bisa digunakan untuk beragam produk pangan seperti rempeyek, kerupuk, cookies, dan beragam produk ekstrudat (makaroni). Fermentasi pati ubi kayu dapat meningkatkan sifat granula pati, meningkatkan daya kembang (Armanto dkk., 2008), dan menurunkan kadar amilosa (Kustyawati dkk., 2013). Penelitian ini bertujuan untuk mengkarakterisasi sifat-sifat fisikokimia pati ubi kayu terfermentasi oleh keempat jenis khamir indigenus tapai ( $C$. guilliermondii, T. mucoides, $S$. fibuligera, dan C. tropicalis) dengan waktu fermentasi yang berbedabeda yaitu 24 jam, 48 jam dan 72 jam.

\section{METODE PENELITIAN}

\section{Bahan}

Bahan utama yang digunakan yaitu pati ubi kayu yang diekstrak dari penelitian sebelumnya dari ubi kayu varietas Kaspro. Media untuk pertumbuhan khamir adalah Malt extract broth (MEB) (Merck, 1053970500) dengan tambahan Bacteriological Agar (Oxoid, LP 0011) untuk membuat MEA. Isolat khamir indigenus tapai ubi kayu yang diisolasi dari penelitian sebelumnya yaitu Candida guilliermondii, Trichosporon mucoides, Saccharomycopsis fibuligera, dan Candida tropicalis.

\section{Alat}

Alat yang digunakan dalam penelitian yaitu; saringan ukuran (80 mesh), otoklaf (Tomy autoclave High Pressure Steam Sterilizer ES-315), sentrifus (Yenaco model YC-180), neraca analitik (Precisa ES 2200 C), shaker waterbath (SBS40-Stuard), vortek (Genie 2 Scientific Industries), oven (Air Concept Froilabo), inkubator (Air Concept Froilabo). Alat untuk analisis meliputi Rapid Visco Analyzer (RVA Tec Master, Perten, Swedia), Spektroskopi FT-IR (fourier transform infrared Alpha, Brucker, USA), Differential Scanning Calorimetry (DSC Thermo Plus Evo Rigaku DSC2830, Jepang), pH meter (Horiba Navi@pH), Spektrofotometer (Hitachi U2900 Spectrophotometer), Scanning electrone microscope (Hitachi, TM 3000, Tokyo, Japan).

\section{Fermentasi Pati Ubi Kayu oleh Khamir Indigenus Tapai}

Fermentasi pati ubi kayu oleh khamir indigenus tapai (C. guilliermondii, T. mucoides, S. fibuligera, dan C. tropicalis) dilakukan dengan cara sebanyak $30 \mathrm{~g}$ pati ubi kayu ditambah air steril $(60 \mathrm{ml})$. Selanjutnya diinokulasikan dengan $3 \mathrm{ml}(5 \%)$ kultur murni isolat khamir indigenus tapai yang berumur 24 jam dari masa peremajaan. Pati ubi kayu difermentasi pada suhu $28^{\circ} \mathrm{C}$ 
selama 24 jam, 48 jam, dan 72 jam. Selanjutnya endapan pati diambil dan dipisahkan dari air rendaman/s/urry pati ubi kayu. Endapan pati dikeringkan pada suhu $50{ }^{\circ} \mathrm{C}$ selama 24 jam menggunakan alat pengering (oven). Pati ubi kayu terfermentasi diayak dengan ayakan ukuran 80 mesh dan selanjutnya dikarakterisasi sifat-sifat fisikokimianya. Analisis sifat fisik makrostruktur granula pati menggunakan SEM, sedangkan profil gugus fungsi diamati dengan alat FT-IR yang keduanya dilakukan hanya pada pati yang difermentasi paling lama. Hal ini mengacu pada penelitian sebelumnya (Jayus dkk., 2016) bahwa makrostruktur pati singkong akan nampak teramati perubahannya dengan pengamatan SEM jika difermentasi lebih dari 48 jam. Oleh karena itu dalam penelitian ini dilakukan penapisan pengamatan makrostruktur pati singkong hanya pada pati alami (tanpa fermentasi) dan pati terfermentasi selama 72 jam.

\section{Analisis Pertumbuhan Khamir Selama Fermetasi Pati Ubi Kayu}

Air rendaman ubi kayu fermentasi diambil sebanyak 1 $\mathrm{ml}$ dan diinokulasikan pada $9 \mathrm{ml}$ larutan garam fisiologis. Pengenceran dilakukan dari seri $10^{-1}$ hingga $10^{-7}$. Empat seri pengenceran $\left(10^{-4}, 10^{-5}, 10^{-6}\right.$ dan $\left.10^{-7}\right)$ diambil sebanyak $1 \mathrm{ml}$ selanjutnya dilakukan pemupukan dengan media MEA menggunakan metode agar tuang dan diinkubasi pada suhu $28^{\circ} \mathrm{C}$ selama 48 jam. Koloni khamir yang tumbuh pada tiap cawan petri dihitung dengan menggunakan rumus perhitungan sebagai berikut:

$\mathrm{N}=\frac{\sum \mathrm{C}}{\left[\left(1 \times \mathrm{n}_{1}\right)+\left(1 \times \mathrm{n}_{2}\right)\right] \times(\mathrm{d})}$

Keterangan:

$\mathrm{N}=$ Jumlah koloni

$\Sigma \mathrm{C}=$ Jumlah seluruh koloni yang dihitung

$\mathrm{n} 1=$ jumlah cawan pada pengenceran 1

$\mathrm{n} 2$ = jumlah cawan pada pengenceran 2

$\mathrm{d}=$ Tingkat pengenceran

\section{Analisis Tingkat Keasaman Slurry (Air Rendaman)}

Keasaman $\mathrm{pH}$ air rendaman diukur dengan $\mathrm{pH}$ meter (Horiba Navi@pH). Sebanyak 10 ml air rendaman diambil dan diukur nilai pHnya secara periodik tiap 24 jam.

\section{Analisis Sifat Pasta Pati Ubi Kayu Terfermentasi Khamir Indigenus Tapai}

Sebanyak $3 \mathrm{~g}$ sampel (pati kering) ditimbang dalam wadah RVA, lalu ditambahkan $25 \mathrm{ml}$ akuades. Parameter yang diamati pada pengukuran dengan RVA mencakup viskositas puncak, trough, breakdown, viskositas akhir, setback, waktu puncak, dan suhu pasting. Selama proses analisis (dalam alat RVA) pati mengalami fase pemanasan dan pendinginan yang diputar pada wadah sampel dengan kecepatan $160 \mathrm{rpm}$. Pada satu menit pertama dilakukan pemanasan awal sampai suhu mencapai $50^{\circ} \mathrm{C}$. Selanjutnya, suhu pemanasan dinaikkan hingga $95^{\circ} \mathrm{C}$. Pada menit ke-8,5 suhu sampel dijaga konstan pada 95 ${ }^{\circ} \mathrm{C}$ selama 5 menit. Suhu sampel kemudian diturunkan kembali ke $50^{\circ} \mathrm{C}$ (pada menit ke 13) dan dipertahankan pada suhu $50^{\circ} \mathrm{C}$ selama 2 menit hingga menit ke-14.

Analisis kadar amilosa dilakukan menurut AOAC, (1995). Analisis daya kembang pati dilakukan dengan cara pati ubi kayu $(0,4 \mathrm{~g}$ basis kering) ditimbang dengan tepat dan dimasukkan pada tabung sentrifus kemudian ditambahkan $10 \mathrm{ml}$ aquades. Larutan pati dipanaskan pada suhu $65^{\circ} \mathrm{C}, 75^{\circ} \mathrm{C}$, dan $85^{\circ} \mathrm{C}$ selama 30 menit. Selanjutnya, sampel didinginkan pada suhu ruang yang kemudian larutan diendapkan dengan alat sentrifus pada kecepatan $3,000 \times \mathrm{g}$ selama 15 menit (Katekhong dkk., 2012). Pengulangan pengukuran dilakukan sebanyak tiga kali. Nilai daya kembang dihitung dengan menggunakan persamaan sebagai berikut:

Nilai daya kembang $=\frac{\text { berat basah endapan pati }(g)}{\text { berat kering pati }(g)} \times 100 \%$

\section{Analisis Sifat Termal Pati Ubi Kayu Terfermentasi Khamir Indigenus Tapai}

Pengukuran sifat termal pati ubi kayu menggunakan alat DSC. Sebelum pengukuran, alat dikalibrasi menggunakan indium (titik leleh $156,78^{\circ} \mathrm{C}$ ). Sebanyak $2 \mathrm{mg}$ sampel dimasukkan kedalam pan aluminium dan dilakukan penutupan secara hermetis. Pengukuran dilakukan pada kisaran suhu $30-140{ }^{\circ} \mathrm{C}$ dengan heating rate $10{ }^{\circ} \mathrm{C} /$ menit untuk mendapatkan grafik (Chinsamran dkk., 2005).

\section{Analisis Gugus Fungsi Pati Ubi Kayu Terfermentasi Khamir Indigenus Tapai}

Analisis gugus fungsi pati dengan menggunakan alat Fourier Transform Infrared Spectroscopy (FT-IR). Sampel yang dipilih untuk diamati profil FT-IR nya adalah pati ubi kayu terfermentasi 72 jam. Sebanyak 5 ul sampel diletakkan pada wadah silikon, wadah tersebut kemudian diletakkan pada unit pembaca mikro (HTS-XT, Bruker Optics GbH, Ettlinger, Jerman). Kemudian sinar inframerah akan dilewatkan ke sampel pada panjang gelombang $4000 \mathrm{~cm}^{-1}$ sampai $400 \mathrm{~cm}^{-1}$. Gelombang yang diteruskan oleh sampel akan ditangkap oleh detektor yang terhubung ke komputer yang akan memberikan gambaran spektrum sampel yang diuji. Analisis gugus fungsi suatu sampel dilakukan dengan membandingkan pita absorbsi yang terbentuk pada spektrum inframerah menggunakan program OPUS (versi 6,5 Bruker, Ettingen, Jerman).

\section{Analisis Makroskopi Granula Pati Ubi Kayu Terfermentasi Khamir Indigenus Tapai}

Gambar morfologi granula pati diamati dengan menggunakan scanning electrone microscope (SEM, Hitachi, TM 3000, Tokyo, Japan) pada 15,0 kV. Sampel pati ubi kayu terfermentasi 72 jam dipilih untuk dianalisis SEM karena memiliki nilai pH paling rendah setelah difermentasi. Dengan demikian lebih nampak nyata pengaruh fermentasi terhadap pati. Sampel ditaburkan pada perekat dua sisi cellophane yang direkatkan pada aluminum stubs, perbesaran dilakukan pada 1000x. 


\section{HASIL DAN PEMBAHASAN}

\section{Pertumbuhan Khamir Selama Fermentasi Pati Ubi Kayu}

Pati ubi kayu difermentasi secara terendam menggunakan khamir indigenus tapai yaitu $C$. guilliermondii, T. mucoides, S. fibuligera, dan C. tropicalis. Pertumbuhan khamir dan perubahan $\mathrm{pH}$ air rendaman pati terfermentasi diamati selama 24, 48, dan 72 jam yang hasilnya ditunjukkan seperti pada Gambar 1.

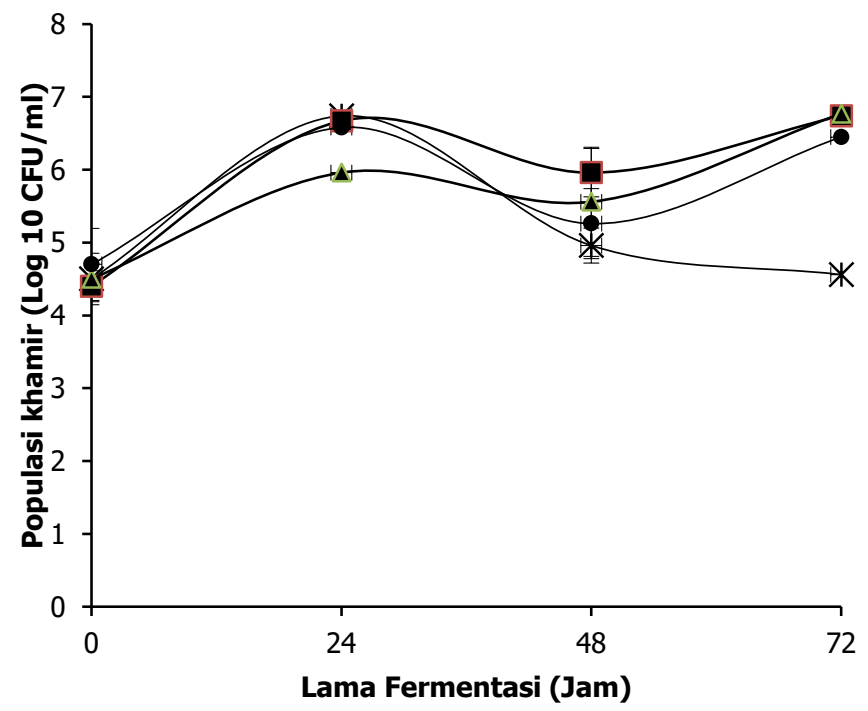

Gambar 1. Populasi khamir air rendaman selama fermentasi pati ubi kayu oleh $C$. guilliermondii (-ж-), T. mucoides (-口-), $S$. fibuligera (- $\mathbf{\Lambda}-)$, C. tropicalis (-0-) selama fermentasi 24,48 , dan 72 jam.

Pertumbuhan $S$. fibuligera lebih cepat dibandingkan dengan C. guilliermondii, T. mucoides atau C. tropicalis. Populasi $S$. fibuligera setelah inkubasi 24 jam, 48 jam dan 72 jam berturut-turut yaitu $5,96 \log _{10} \mathrm{CFU} / \mathrm{ml}, 5,56 \log _{10}$ $\mathrm{CFU} / \mathrm{ml}, 6,77 \log _{10} \mathrm{CFU} / \mathrm{ml}$. Populasi $C$. guilliermondiilebih rendah daripada $S$. fibuligera berturut-turut setelah inkubasi pada 24 jam, 48 jam dan 72 jam yaitu 6,47 $\log _{10}$ $\mathrm{CFU} / \mathrm{ml}, 4,96 \log _{10} \mathrm{CFU} / \mathrm{ml}$, dan 4,56 $\log _{10} \mathrm{CFU} / \mathrm{ml}$. Populasi pertumbuhan $C$. tropicalis setelah inkubasi 24 jam yaitu $6,58 \log _{10} \mathrm{CFU} / \mathrm{ml}$, setelah inkubasi 48 jam yaitu $5,26 \log _{10} \mathrm{CFU} / \mathrm{ml}$, dan setelah inkubasi pada 72 jam yaitu $6,45 \log _{10} \mathrm{CFU} / \mathrm{ml}$. Populasi T. mucoides setelah inkubasi pada 24 jam yaitu $6,67 \log _{10} \mathrm{CFU} / \mathrm{ml}$, setelah inkubasi pada 48 jam yaitu $5,96 \log _{10} \mathrm{CFU} / \mathrm{ml}$, dan setelah inkubasi 72 jam yaitu $6,74 \log _{10} \mathrm{CFU} / \mathrm{ml}$.

Penelitian lainnya melaporkan bahwa peningkatan populasi khamir ketika fermentasi ubi kayu menggunakan $S$. cerevisiae, L. plantarum, dan $R$. orizae terjadi setelah difermentasi selama 24 jam (Gunawan dkk., 2015). Reboucas dkk., (2016) melaporkan peningkatan populasi khamir saat fermentasi pati ubi kayu secara alami selama 1 hari sebesar $7,8 \log _{10} \mathrm{CFU} / \mathrm{ml}$. Fermentasi pati asam menunjukkan peningkatan populasi khamir hingga 6,2 $\log _{10} \mathrm{CFU} / \mathrm{ml}$.

\section{Tingkat Keasaman Air Rendaman Selama Fermentasi Pati Ubi Kayu}

Banyak keuntungan yang berkaitan dengan penggunaan starter pada fermentasi, yaitu mempercepat keasaman produk, menghambat pertumbuhan jamur, dan bakteri patogen yang tumbuh pada produk serta diperolehnya kualitas produk yang konsisten (Freire dkk., 2015). Nilai pH adalah salah satu faktor penting untuk memaksimalkan pertumbuhan pada suhu fermentasi yang tepat. Pada air pati ubi kayu terfermentasi $C$. guilliermondii, $T$. mucoides, $S$. fibuligera, dan C. tropicalis nilai $\mathrm{pH}$ menurun secara berurutan yaitu 5,7 ke 4,19, dari 5,7 ke 4,68, dari 5,57 ke 4,17 , dan dari 5,57 menjadi 3,99 pada $28^{\circ} \mathrm{C}$ (Gambar 2).

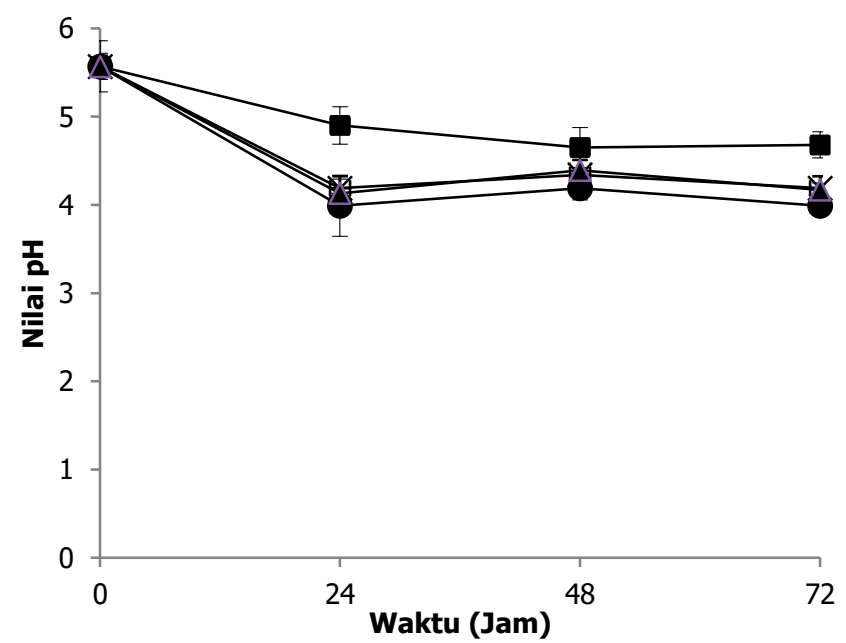

Gambar 2. Nilai pH air rendaman fermentasi pati ubi kayu oleh C. guilliermondii (-ж-), T. mucoides (-!-), $S$. fibuligera $(-\mathbf{\Delta}-), C$. tropicalis (-0) selama fermentasi 24 , 48, dan 72 jam

Gambar 2 menunjukkan penurunan $\mathrm{pH}$ pati selama fermentasi oleh khamir indigenus, akan tetapi penurunan $\mathrm{pH}$ tersebut tidak besar seperti halnya jika fermentasi dilakukan oleh bakteri asam laktat. Freire dkk., (2015) melaporkan bahwa penurunan nilai pH juga terjadi pada fermentasi ubi kayu, fermentasi cauim, dan fermentasi pupuru. Laporan Gunawan dkk., (2015) juga menjelaskan bahwa penurunan nilai pH dengan semakin lamanya waktu fermentasi pada ubi kayu terjadi ketika difermentasi menggunakan $S$. cerevisiae, L. plantarum, dan $R$. oryzae. Penurunan kondisi pH dari $L$. plantarum, $S$. cerevisiae, dan $R$. oryzae berurutan yaitu $5,6-3,9 ; 5,8-$ 4,4, dan 6,6-3,9 dengan inkubasi $30^{\circ} \mathrm{C}$. Ilowefah dkk., (2015) menjelaskan bahwa keasaman akan mempengaruhi rasa, aroma, daya simpan, dan kualitas produk fermentasi.

Khamir yang mampu tumbuh pada substrat berpati berarti mampu menghasilkan enzim amilase untuk mendegradasi pati menjadi glukosa sebagai sumber karbonnya. Schwan dkk., (2007) melaporkan C. tropicalis termasuk salah satu jenis khamir yang menghasilkan amilase. Menurut penjelasan De dkk., (2014) selama fermentasi pada substrat berpati, khamir 


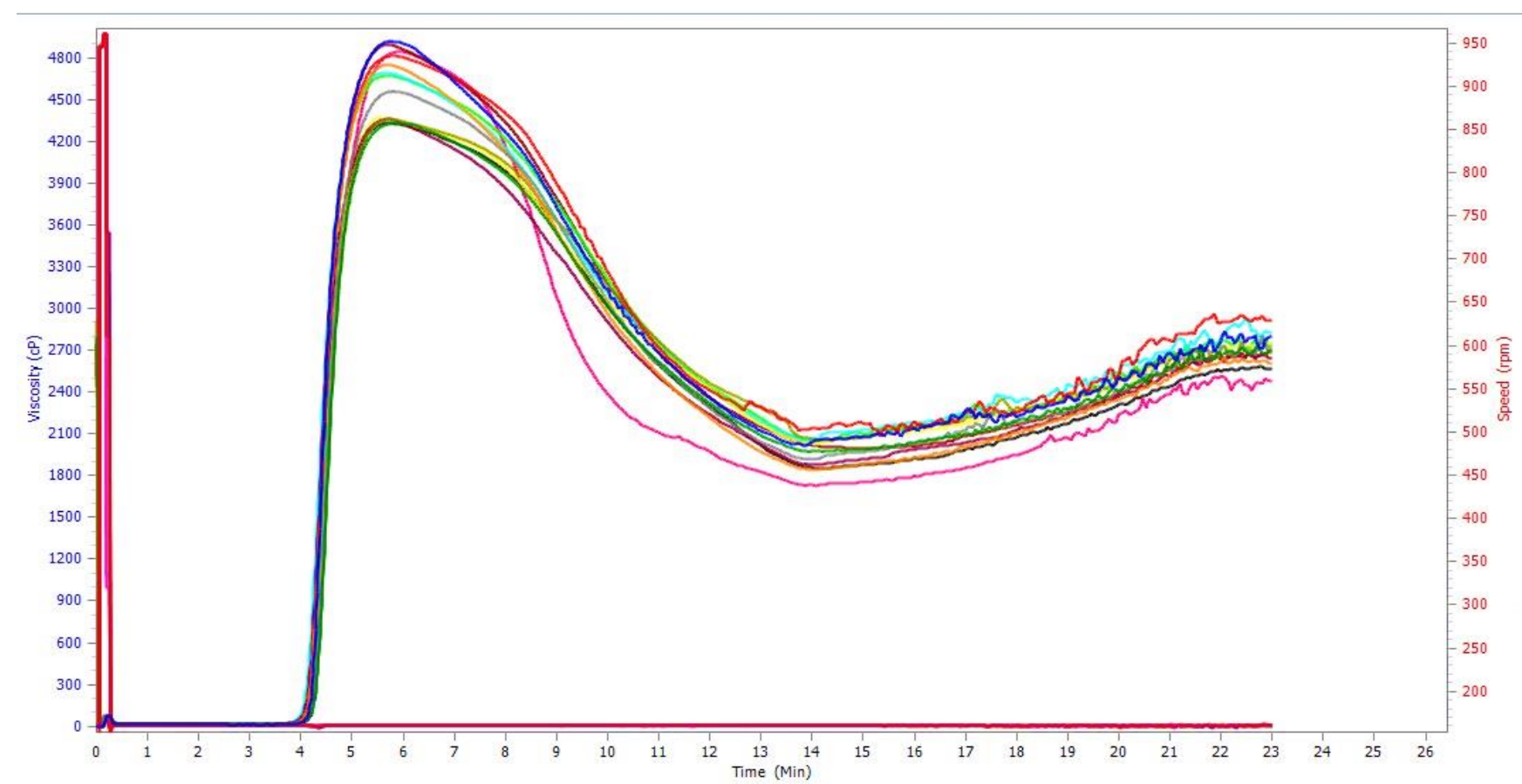

Keterangan: a). C. guilliermondii selama 24 jam (A24J-); b). C. guilliermondii selama 48 jam (A48J —); c). C.guilliermondii selama 72 jam (A72J ); d). T. mucoides selama 24 jam (B24J ) ) e). T. mucoides selama 48 jam (B48J_); f). T. mucoides selama 72 jam (B72J- ); g). S. fibuligera selama 24 jam (C24J ); h). S. fibuligera selama 48 jam (C48J ); i). S. fibuligera selama 72 jam (C72J-); j). C. tropicalis selama 24 jam (D24J-); k). C. tropicalis selama 48 jam (D48J-); I). C. tropicalis selama 72 jam (D72J-); m). Pati ubi kayu tanpa fermentasi (kontrol $\longrightarrow$ )

\section{Gambar 3. Sifat pasta pati ubi kayu terfermentasi dengan variasi perendaman}

tidak hanya menghasilkan enzim amilolitik tetapi juga asam organik. Keberadaan asam organik tersebut juga berperan dalam perubahan sifat fungsional pati ubi kayu. Freire dkk., (2015) juga menjelaskan bahwa selama fermentasi khamir menyebabkan penurunan $\mathrm{pH}$ serta menimbulkan profil aroma (harum) yang disukai. Hal ini disebabkan oleh pelepasan unsur fenolik akibat $\mathrm{pH}$ yang semakin rendah (Ilowefah dkk., 2015).

\section{Sifat Fisikokimia Pati Ubi Kayu Terfermentasi Khamir Indigenus Tapai}

\section{Sifat Pasta Pati Ubi Kayu Terfermentasi Khamir Indigenus Tapai}

Sifat pasta dari pati ubi kayu terfermentasi diukur berdasarkan siklus pemanasan-pendinginan (Gambar 3). Kurva pasta pati ubi kayu terfermentasi menunjukkan adanya ketidaksamaan profil kurva. Pati ubi kayu tanpa fermentasi mengindikasikan berbeda dengan viskositas pati ubi kayu terfermentasi oleh isolat khamir. Pati ubi kayu terfermentasi oleh strain khamir yang berbeda menunjukkan kurva viskositas tumpang tindih yang mengindikasikan kemiripan sifat pasta. Profil gelatinisasi pati ubi kayu yang difermentasi menggunakan khamir $C$. guilliermondii, T. mucoides, S. fibuligera, dan C. tropicalis selama 24, 48, dan 72 jam memiliki pola yang mirip (Gambar 3). Secara detail profil masing-masing pati dirinci pada Tabel 1 yang meliputi puncak dan akhir viskositas/kekentalan pasta, waktu tercapainya puncak viskositas dan suhu pasta yang tercapai.
Sifat-sifat pasta pati ubi kayu ditentukan dengan alat RVA. Hasil menunjukkan proses fermentasi mampu mengubah sifat-sifat pasta pati ubi kayu seperti yang ditunjukkan pada Tabel 1. Fermentasi meningkatkan nilai viskositas trough, breakdown, dan viskositas akhir pati ubi kayu dibandingkan kontrol pati ubi kayu. Pati ubi kayu alami memiliki viskositas puncak yang tinggi yaitu $4844 \mathrm{CP}$, dan mengalami penurunan viskositas breakdown yang cukup tajam yaitu $1714 \mathrm{cP}$. Pati ubi kayu terfermentasi khamir indigenus tapai memiliki viskositas puncak, dan viskositas breakdown lebih tinggi yaitu berkisar antara $4331 \mathrm{cP}$ - $4918 \mathrm{CP}$ untuk viskositas puncak, dan 1831 CP - 2072 CP untuk viskositas breakdown. Pati yang memiliki puncak viskositas tinggi dan mengalami penurunan viskositas breakdown yang tajam mengindikasikan bahwa pati tersebut kurang tahan atau kurang stabil selama proses pemanasan (Rahmiati dkk., 2016). Yuliana dkk., (2014) menjelaskan rendahnya kemampuan pati ketika dipanaskan dengan pengadukan selama pemasakan bisa dilihat dari nilai breakdown pati terfermentasi yang lebih tinggi dibandingkan dengan pati tanpa fermentasi.

Pati ubi kayu terfermentasi oleh T. mucoides selama 48 jam memiliki viskositas setback tertinggi yaitu $833 \mathrm{cP}$. Hal ini sesuai dengan viskositas akhir yang tinggi pula yaitu $2914 \mathrm{CP}$, dibanding viskositas setback pati ubi kayu kotrol yaitu 753 cP. Menurut Rahmiati dkk., (2016) viskositas setback tinggi menunjukkan pati cenderung lebih mudah mengalami retrogradasi, sehingga semakin mudah membentuk gel selama pendinginan. Viskositas 
Tabel 1. Sifat-sifat pasta pati ubi kayu terfermentasi

\begin{tabular}{lcccccccc}
\hline Sampel & $\begin{array}{c}\text { Viskositas } \\
\text { puncak (CP) }\end{array}$ & $\begin{array}{c}\text { Trough } \\
1(\mathrm{CP})\end{array}$ & $\begin{array}{c}\text { Breakdown } \\
(\mathrm{CP})\end{array}$ & $\begin{array}{c}\text { Viskositas } \\
\text { akhir (CP) }\end{array}$ & $\begin{array}{c}\text { Setback } \\
(\mathrm{CP})\end{array}$ & $\begin{array}{c}\text { Waktu puncak } \\
\text { (menit) }\end{array}$ & $\begin{array}{c}\text { Suhu pasting } \\
\left({ }^{\circ} \mathrm{C}\right)\end{array}$ & $\begin{array}{c}\text { Amilosa (\%) } \\
(\%)\end{array}$ \\
\hline Pati ubi kayu & $4844 \pm 2,12$ & $1727 \pm 1,41$ & $1714 \pm 2,12$ & $2480 \pm 1,41$ & $753 \pm 0,00$ & $5,93 \pm 0,02$ & $67,95 \pm 0,04$ & $15,85 \pm 0,03$ \\
A 24Jam & $4918 \pm 1,41$ & $2015 \pm 1,41$ & $2001 \pm 2,12$ & $2796 \pm 2,83$ & $781 \pm 1,41$ & $5,73 \pm 0,05$ & $68,30 \pm 0,07$ & $15,61 \pm 0,03$ \\
A 48Jam & $4331 \pm 2,83$ & $1971 \pm 2,12$ & $1955 \pm 0,71$ & $2700 \pm 1,41$ & $729 \pm 0,71$ & $5,87 \pm 0,05$ & $68,35 \pm 0,01$ & $11,28 \pm 0,03$ \\
A 72Jam & $4561 \pm 1,41$ & $1915 \pm 2,83$ & $1901 \pm 0,71$ & $2721 \pm 1,41$ & $806 \pm 1,41$ & $5,80 \pm 0,02$ & $68,30 \pm 0,03$ & $12,34 \pm 0,04$ \\
B 24Jam & $4752 \pm 2,83$ & $1843 \pm 2,12$ & $1831 \pm 0,71$ & $2604 \pm 1,41$ & $761 \pm 0,71$ & $5,67 \pm 0,02$ & $67,90 \pm 0,04$ & $11,22 \pm 0,03$ \\
B 48Jam & $4815 \pm 2,12$ & $2081 \pm 1,41$ & $2072 \pm 1,41$ & $2914 \pm 2,12$ & $833 \pm 0,71$ & $5,80 \pm 0,05$ & $67,95 \pm 0,04$ & $13,76 \pm 0,03$ \\
B 72Jam & $4359 \pm 2,12$ & $2053 \pm 1,41$ & $2037 \pm 2,83$ & $2681 \pm 1,41$ & $628 \pm 2,83$ & $5,73 \pm 0,03$ & $68,35 \pm 0,03$ & $14,73 \pm 0,10$ \\
C 24Jam & $4359 \pm 2,83$ & $1877 \pm 1,41$ & $1860 \pm 0,71$ & $2641 \pm 0,71$ & $764 \pm 0,71$ & $5,67 \pm 0,02$ & $67,60 \pm 0,04$ & $13,85 \pm 0,13$ \\
C 48Jam & $4371 \pm 1,41$ & $2027 \pm 2,83$ & $2011 \pm 1,41$ & $2754 \pm 1,41$ & $727 \pm 1,41$ & $5,53 \pm 0,04$ & $67,90 \pm 0,01$ & $14,22 \pm 0,16$ \\
C 72Jam & $4333 \pm 1,41$ & $1850 \pm 0,71$ & $1836 \pm 2,83$ & $2569 \pm 1,41$ & $719 \pm 2,12$ & $5,67 \pm 0,04$ & $68,40 \pm 0,05$ & $14,50 \pm 0,10$ \\
D 24Jam & $4692 \pm 1,41$ & $2058 \pm 0,71$ & $2042 \pm 1,41$ & $2829 \pm 1,41$ & $771 \pm 0,71$ & $5,60 \pm 0,01$ & $67,20 \pm 0,04$ & $14,68 \pm 0,03$ \\
D 48Jam & $4673 \pm 2,12$ & $2045 \pm 2,12$ & $2029 \pm 0,71$ & $2744 \pm 2,83$ & $699 \pm 0,71$ & $5,73 \pm 0,02$ & $67,95 \pm 0,32$ & $15,47 \pm 0,00$ \\
D 72Jam & $4896 \pm 2,12$ & $1992 \pm 2,12$ & $1979 \pm 2,12$ & $2688 \pm 2,83$ & $696 \pm 0,71$ & $5,67 \pm 0,03$ & $68,35 \pm 0,04$ & $15,47 \pm 0,00$ \\
\hline
\end{tabular}

setback merupakan suatu parameter yang dipakai untuk melihat kecenderungan retrogradasi, dan sineresis suatu pasta pati. Viskositas setback diperoleh dari selisih antara viskositas akhir dengan trough 1.

Pengaruh fermentasi terhadap viskositas tepung ubi kayu (varietas Wikau Maombou) juga dilaporkan oleh Wahyuni dkk., (2017). Viskositas puncak tepung ubi kayu varietas Wikau Maombou yaitu $401 \mathrm{cP}$ dengan suhu pasta $74,1{ }^{\circ} \mathrm{C}$, sedangkan viskositas puncak dan suhu pasta tepung ubi kayu yaitu $3550 \mathrm{cP}$, dan $67,7^{\circ} \mathrm{C}$. Tingginya viskositas puncak, waktu puncak, dan viskositas final dari pati ubi kayu terfermentasi mempunyai hubungan dengan aktivitas glukoamilase yang dapat meningkatkan profil gelatinisasi pati (Dura dkk., 2014).

Suhu awal gelatinisasi pati ubi kayu tanpa fermentasi (pati kontrol) yaitu $67,95{ }^{\circ} \mathrm{C}$, sedangkan suhu awal gelatinisasi pati ubi kayu terfermentasi yaitu $68,40{ }^{\circ} \mathrm{C}$. Waktu puncak gelatinisasi pati ubi kayu tanpa fermentasi yaitu 5,93 menit, sedangkan waktu puncak gelatinisasi pati ubi kayu terfermentasi yaitu 5,53 menit. Copeland dkk., (2009) menjelaskan bahwa nilai waktu puncak dan viskositas puncak dapat mengindikasikan kapasitas pati dalam mengikat air. Dengan demikian juga mengindikasikan bahwa granula pati sudah mulai mengembang, dan pecah (tergelatinisasi). Rendahnya nilai setback akibat proses fermentasi bisa mengindikasikan lambatnya proses retrogradasi pada produk akhir.

Kadar amilosa pati ubi kayu terfermentasi lebih rendah yaitu $11,28 \%-15,61 \%$ daripada kadar amilosa pati ubi kayu alami $(15,85 \%)$ yang ditunjukkan pada Tabel 1 . Hal ini diduga karena amilosa terdegradasi oleh enzim amilolitik (amilase) yang diproduksi oleh khamir. Seperti yang dilaporkan oleh Ilowefah dkk. (2015) bahwa amilase akan menghidrolisis amilosa menghasilkan maltosa dan glukosa. Selanjutnya glukosa yang terbentuk dikonsumsi oleh khamir. Penurunan kadar amilosa juga terjadi pada fermentasi pati ubi kayu menggunakan $S$. cerevisiae yang dilakukan oleh Kustyawati dkk. (2013). Yuliana dkk., (2014) menjelaskan bahwa komposisi amilosa yang lebih rendah akan meningkatkan komposisi amilopektin sehingga dapat meningkatkan daya kembang pati, dengan demikian granula pati lebih cepat terlarut tercapainya suhu awal gelatinisasi.

\section{Sifat Termal Pati Ubi Kayu Terfermentasi Khamir Indigenus Tapai}

Sifat termal pati ubi kayu terfermentasi oleh khamir indigenus tapai ditunjukkan pada Gambar 4, dan Tabel 2. Menurut Wang dkk. (2013), granula pati yang mulai kehilangan sifat polarisasi disebut awal gelatinisasi (To), dan pada saat $98 \%$ polarisasi granula pati menjadi hilang disebut akhir gelatinisasi (Tc).

Pati ubi kayu terfermentasi menunjukkan peningkatan persentase nilai To, dan Tp dibanding pati ubi kayu kontrol, berurutan yaitu 1,57\%-5,18\%, dan 0,43\%-2,45\%. Pati ubi kayu terfermentasi khamir indigenus tapai memiliki kisaran nilai To, dan Tp berurutan yaitu $64,7^{\circ} \mathrm{C}-67{ }^{\circ} \mathrm{C}$, dan $69,1^{\circ} \mathrm{C}-71,2^{\circ} \mathrm{C}$, dibandingkan dengan nilai To, dan Tp pati ubi kayu alami (kontrol) yaitu $64,2^{\circ} \mathrm{C}$, dan $69,3^{\circ} \mathrm{C}$. Sifat termal yang diperoleh pada penelitian ini menunjukkan sifat yang konsisten dengan pati asam ubi kayu. Hal ini mengindikasikan bahwa proses fermentasi mampu meningkatkan suhu To, dan Tp yaitu berurutan berkisar antara $58,59{ }^{\circ} \mathrm{C}-60,67{ }^{\circ} \mathrm{C}$, dan $64,88{ }^{\circ} \mathrm{C}-67,03{ }^{\circ} \mathrm{C}$ dibandingkan dengan To, dan Tp pati ubi kayu alami sebesar $57,94^{\circ} \mathrm{C}$, dan $63,48{ }^{\circ} \mathrm{C}$. Menurut Alonso dkk. (2016), peningkatan nilai suhu Tp karena keasaman mengindikasikan bahwa granula pati memiliki komposisi daerah kristalin yang lebih banyak daripada daerah amorf.

Pati ubi kayu terfermentasi oleh khamir indigenus tapai menunjukkan penurunan nilai $\mathrm{Tc}, \Delta \mathrm{T}$, dan $\Delta \mathrm{H}$ 


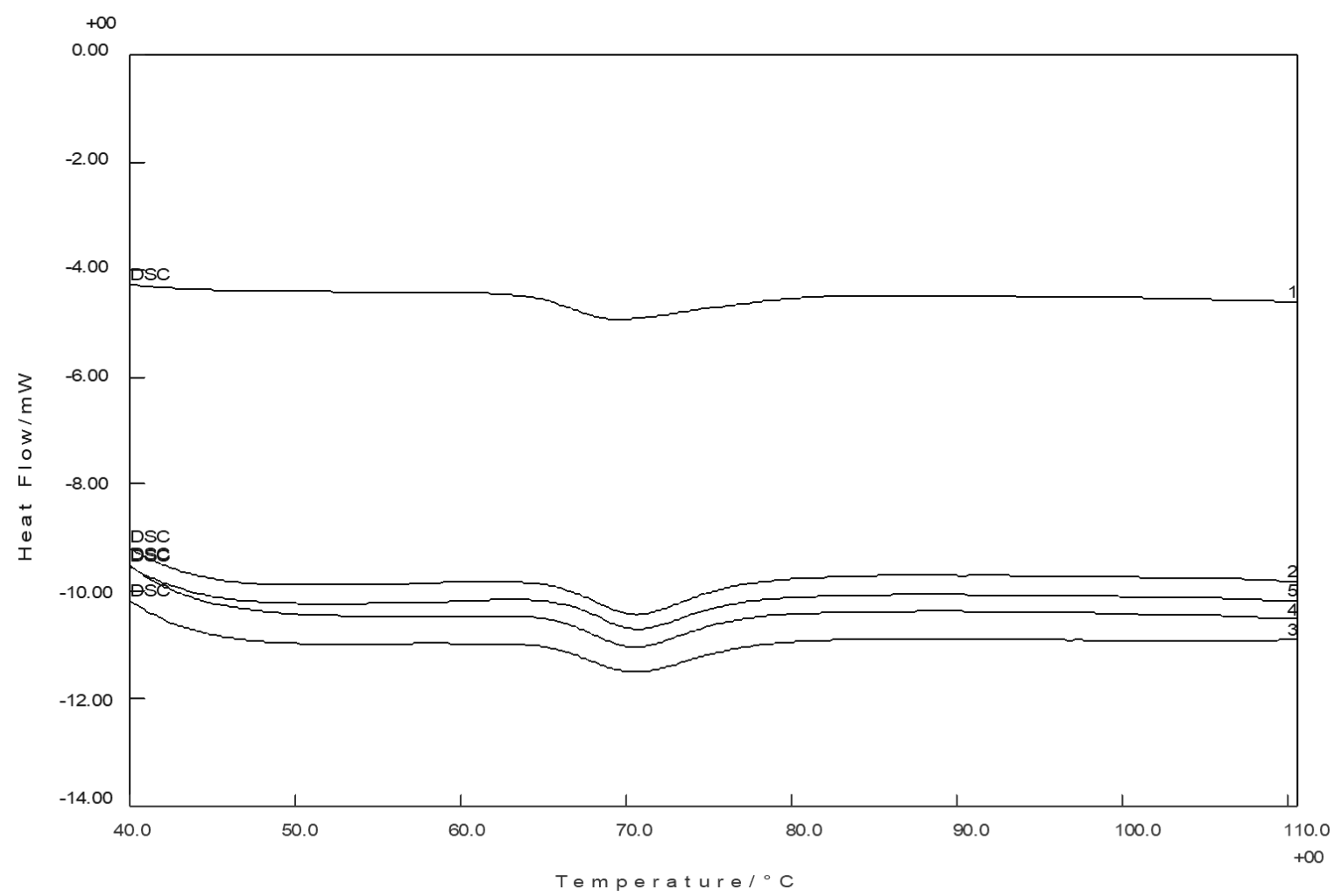

Keterangan: pati ubi kayu kontrol (1), pati ubi kayu terfermentasi selama 72 jam dengan perlakuan inokulasi $C$. guilliermondii (2), $T$. mucoides (3), S. fibuligera (4), C. tropicalis (5)

Gambar 4. Kurva sifat thermal pati ubi kayu

dibandingkan pati kontrol (Tabel 2). Zeng dkk., (2015) menjelaskan terjadinya penurunan $\Delta T$ mengindikasikan terbentuknya struktur kristalin yang sempurna. Pati terfermentasi mengalami penurunan nilai $\Delta \mathrm{T}, \Delta \mathrm{H}$, dan $\mathrm{TC}$, berurutan yaitu berkisar antara $7,1^{\circ} \mathrm{C}-9,7^{\circ} \mathrm{C}, 4,84-6,38$ $\mathrm{J} / \mathrm{g}$, dan $73,9-75{ }^{\circ} \mathrm{C}$, sedangkan pati ubi kayu tanpa fermentasi (kontrol) memiliki nilai $\Delta \mathrm{T}, \Delta \mathrm{H}$, dan $\mathrm{Tc}$ berurutan yaitu $11,2{ }^{\circ} \mathrm{C}, 9,15 \mathrm{~J} / \mathrm{g}$, dan $75,4^{\circ} \mathrm{C}$. Entalpi gelatinisasi $(\Delta H)$ granula pati merupakan jumlah energi yang diperlukan untuk memotong ikatan rangkap heliks. Pati ubi kayu yang memiliki tingkat keasaman tinggi menunjukkan penurunan nilai $\Delta \mathrm{H}$ (Garcia dkk., 2016).

Tabel 2. Sifat termal pati ubi kayu terfermentasi oleh starter khamir, suhu awal (To), suhu puncak (Tp), suhu akhir (Tc), dan entalpi gelatinisasi $(\Delta \mathrm{H})$

\begin{tabular}{|c|c|c|c|c|c|c|c|c|c|}
\hline $\begin{array}{l}\text { Sampel } \\
\text { Terfermentasi } \\
\text { oleh }\end{array}$ & $\begin{array}{l}\text { Lama } \\
\text { fermentasi } \\
\quad(j a m)\end{array}$ & $\mathrm{T}_{0}\left({ }^{\circ} \mathrm{C}\right)$ & $\operatorname{Tp}\left({ }^{\circ} \mathrm{C}\right)$ & $\mathrm{Tc}\left({ }^{\circ} \mathrm{C}\right)$ & $\Delta \mathrm{T}=\mathrm{TC}-\mathrm{T}_{0}\left({ }^{\circ} \mathrm{C}\right)$ & $\Delta \mathrm{H}(\mathrm{J} / \mathrm{g})$ & $\begin{array}{c}\% \\
\text { pening } \\
\text { katan } \\
\mathrm{T}_{0}\end{array}$ & $\begin{array}{c}\% \\
\text { peningkat } \\
\text { anTp }\end{array}$ & $\begin{array}{c}\% \text { peningkatan } \\
\text { Tc }\end{array}$ \\
\hline \multirow[t]{2}{*}{ Pati ubikayu } & - & $64,2 \pm 0,14$ & $69,3 \pm 0,14$ & $75,4 \pm 0,35$ & $11,2 \pm 0,21$ & 9,15 & - & - & - \\
\hline & 24 & $64,7 \pm 0,14$ & $69,1 \pm 0,14$ & $74,4 \pm 0,14$ & $9,7 \pm 0,00$ & 5,28 & 1,57 & $-0,58$ & -4 \\
\hline \multirow[t]{3}{*}{ C. guilliermondii } & 48 & $66,2 \pm 0,42$ & $70,2 \pm 0,14$ & $74,4 \pm 0,21$ & $8,2 \pm 0,21$ & 5,3 & 3,92 & 1,01 & -4 \\
\hline & 72 & $66,5 \pm 0,14$ & $70,5 \pm 0,14$ & $74,9 \pm 0,14$ & $8,4 \pm 0,21$ & 6,38 & 4,40 & 1,44 & $-3,4$ \\
\hline & 24 & $66,4 \pm 0,21$ & $70,4 \pm 0,07$ & $74,2 \pm 0,14$ & $7,8 \pm 0,28$ & 5,38 & 4,24 & 1,29 & $-4,3$ \\
\hline \multirow[t]{3}{*}{ T. mucoides } & 48 & $66,1 \pm 0,07$ & $70,2 \pm 0,28$ & $73,9 \pm 0,07$ & $7,8 \pm 0,35$ & 5,34 & 3,77 & 1,01 & $-4,6$ \\
\hline & 72 & $66 \pm 0,00$ & $70,3 \pm 0,14$ & $74,4 \pm 0,00$ & $8,4 \pm 0,14$ & 5,11 & 3,61 & 1,15 & -4 \\
\hline & 24 & $65,3 \pm 0,07$ & $69,8 \pm 0,07$ & $74 \pm 0,00$ & $8,7 \pm 0,07$ & 5,78 & 2,51 & 0,43 & $-4,5$ \\
\hline \multirow[t]{3}{*}{ S. fibuligera } & 48 & $65,3 \pm 0,14$ & $70,3 \pm 0,07$ & $74 \pm 0,35$ & $8,7 \pm 0,49$ & 5,51 & 2,51 & 1,15 & -45 \\
\hline & 72 & $66,4 \pm 0,14$ & $70,4 \pm 0,21$ & $74,1 \pm 0,14$ & $7,7 \pm 0,00$ & 4,84 & 4,24 & 1,29 & $-4,4$ \\
\hline & 24 & $65,1 \pm 0,07$ & $69,7 \pm 0,14$ & $74,1 \pm 0,14$ & $9 \pm 0,21$ & 5,92 & 2,20 & 0,29 & $-4,4$ \\
\hline \multirow[t]{2}{*}{ C. tropicalis } & 48 & $66,6 \pm 0,07$ & $71,2 \pm 0,21$ & $75,6 \pm 0,85$ & $9 \pm 0,78$ & 5,70 & 4,55 & 2,45 & $-2,5$ \\
\hline & 72 & $67 \pm 0,14$ & $70,6 \pm 0,07$ & $74,1 \pm 0,07$ & $7,1 \pm 0,07$ & 5,06 & 5,18 & 1,58 & $-4,4$ \\
\hline
\end{tabular}


Penurunan $\Delta \mathrm{H}$ terjadi karena asam menyerang bagian primer struktur amorfus granula pati yang merupakan bagian terpenting dalam termodinamis proses gelatinisasi pati (Maribel dkk., 2014). Deteksi perubahan entalpi selama pembacaan scan alat DSC dipengaruhi oleh banyak faktor diantaranya kecepatan scan, kadar air (jumlah dan tipe pelarut), derajat granula pati terhidrasi, sumber botani, kondisi fisik granula pati, dan sensitifitas alat (Alonso dkk., 2016). Angeloni dkk., (2009) melaporkan bahwa pati ubi kayu asam memiliki nilai To yaitu $61,7^{\circ} \mathrm{C}$, Tp $69,4^{\circ} \mathrm{C}$, Tc $71,9^{\circ} \mathrm{C}$, dan $\Delta \mathrm{H} \mathrm{3,3} \mathrm{J} / \mathrm{g}$.

Pati ubi kayu terfermentasi meningkat signifikan $\left(p<0.05 \%\right.$ ) untuk nilai To dari $58,56{ }^{\circ} \mathrm{C}$ menjadi $60,79{ }^{\circ} \mathrm{C}$ dengan beragam kelas keasaman dari 1 sampai 6 (nilai kelas keasaman dari 2,64\% sampai 4,92\%). Peningkatan nilai Tp dari $63,37^{\circ} \mathrm{C}$ menjadi $64,80^{\circ} \mathrm{C}$ terjadi pada pati ubi kayu terfermentasi. Meningkatnya keasamaan dari 1 hingga 6 mengindikasikan sebagian besar daerah kristalin diikat asam dengan sempurna, strukturnya stabil dan kristalin menjadi lebih resisten untuk dihidrolisis oleh rantai karboksil asam organik. Oleh karena itu proses peleburan hanya bisa terjadi pada suhu tinggi (Garcia dkk., 2016).

\section{Daya Kembang Pati Ubi Kayu Terfermentasi}

Kemampuan menyerap air pada fase pati dalam bentuk suspensi cairan tergelatinisasi, dan kapasitas menahan air tersentrifugasi di bawah kondisi terkendali dapat merefleksikan sifat daya kembang yang juga dapat menjelaskan sifat pati tergelatinisasi. Daya kembang pati alami, dan pati ubi kayu terfermentasi ditampilkan pada Tabel 3. Daya kembang semua pati ubi kayu meningkat dengan meningkatnya suhu perlakuan. Pati ubi kayu terfermentasi menunjukkan peningkatan nilai daya kembangnya baik terfermentasi selama 24 jam, 48 jam dan 72 jam.

Tabel 3. Profil daya kembang pati ubi kayu terfermentasi

\begin{tabular}{lcccc}
\hline \multirow{2}{*}{$\begin{array}{l}\text { Sampel } \\
\text { Terfermentasi oleh }\end{array}$} & $\begin{array}{c}\text { Lama } \\
\text { fermentasi } \\
\text { (jam) }\end{array}$ & \multicolumn{4}{c}{ Daya kembang $(\mathrm{g} / \mathrm{g})$ pada suhu $\left({ }^{\circ} \mathrm{C}\right)$} \\
\cline { 3 - 5 } & 0 & $7,3 \pm 0,18$ & $7,8 \pm 0,15$ & $6,8 \pm 0,86$ \\
\hline Pati ubi kayu & & $8,7 \pm 0,44$ & $8,7 \pm 0,19$ & $8,5 \pm 0,81$ \\
kontrol & 24 & $9,4 \pm 0,02$ & $8,8 \pm 0,34$ & $8,6 \pm 0,19$ \\
C. guilliermondii & 48 & $8,6 \pm 0,41$ & $8,4 \pm 0,23$ & $8,4 \pm 0,48$ \\
& 72 & $9,3 \pm 0,09$ & $9,0 \pm 0,02$ & $8,4 \pm 0,51$ \\
& 24 & $9,0 \pm 0,19$ & $8,4 \pm 0,25$ & $8,2 \pm 0,99$ \\
T. mucoides & 48 & $9,4 \pm 0,53$ & $9,5 \pm 0,87$ & $8,9 \pm 0,41$ \\
& 72 & $9,2 \pm 0,67$ & $9,4 \pm 1,13$ & $9,1 \pm 0,51$ \\
& 24 & $9,6 \pm 0,94$ & $10,3 \pm 0,83$ & $9,8 \pm 0,18$ \\
S. fibuligera & 48 & $8,8 \pm 0,53$ & $8,9 \pm 0,65$ & $8,4 \pm 1,06$ \\
& 72 & $9,8 \pm 0,35$ & $10,4 \pm 0,34$ & $9,0 \pm 0,23$ \\
& 24 & $9,4 \pm 0,80$ & $9,8 \pm 0,04$ & $8,9 \pm 0,49$ \\
C. tropicalis & 48 & $8,7 \pm 0,35$ & $8,9 \pm 0,16$ & $8,3 \pm 0,60$ \\
\hline
\end{tabular}

Tabel 3 menunjukkan bahwa proses fermentasi oleh khamir dapat meningkatkan daya kembang pati ubi kayu. Fermentasi selama 24, 48, dan 72 jam menghasilkan daya kembang pati antara $8,4 \mathrm{~g} / \mathrm{g}-10,4 \mathrm{~g} / \mathrm{g}$ pada suhu $75^{\circ} \mathrm{C}$. Seperti yang terjadi pula pada fermentasi tepung ubi kayu Wikau Maombo memiliki daya kembang $8,39 \mathrm{~g} / \mathrm{g}$ pada suhu $90{ }^{\circ} \mathrm{C}$ (Wahyuni dkk., 2017). Zavareze dkk. (2010) melaporkan bahwa pati beras memiliki daya kembang maksimum berkisar $9 \mathrm{~g} / \mathrm{g}-23 \mathrm{~g} / \mathrm{g}$ pada $70{ }^{\circ} \mathrm{C}$, dan di atas $70{ }^{\circ} \mathrm{C}$ hanya akan meningkatkan fraksi terlarut. Pada beras ketan dan tepung gandum kaya amilopektin, nilai daya kembang berkisar antara $5 \mathrm{~g} / \mathrm{g}-24 \mathrm{~g} / \mathrm{g}$, dengan variasi suhu $50{ }^{\circ} \mathrm{C}, 60^{\circ} \mathrm{C}, 70^{\circ} \mathrm{C}, 80^{\circ} \mathrm{C}$, dan $90^{\circ} \mathrm{C}$. Semakin meningkat suhu maka semakin besar nilai daya kembang (Qi dkk., 2015).

\section{Makrostruktur Granula Pati Ubi Kayu Terfermentasi}

Pengamatan makrostruktur granula pati dilakukan pada pati ubi kayu terfermentasi selama 72 jam. Semakin lama fermentasi perubahan yang terjadi semakin nyata. Jayus dkk. (2016) melaporkan bahwa pengamatan granula pati ubi kayu dengan menggunakan alat SEM akan terlihat perbedaannya jika difermentasi lebih dari 48 jam. Pengamatan SEM pada pati ubi kayu yang terfermentasi 24 jam hingga 48 jam kurang menunjukkan perubahan yang signifikan. Gambar 5 menunjukkan morfologi granula pati ubi kayu terfermentasi 72 jam memiliki kemiripan dengan pati ubi kayu alami yaitu memiliki bentuk yang tidak beraturan (irregular). Ukuran granula pati ubi kayu berkisar $2 \mu \mathrm{m}$ $25 \mu \mathrm{m}$. Pati ubi kayu terfermentasi hingga pengamatan menggunakan scanning elektron mikroskop pada perbesaran 1000x menunjukkan permukaan granula pati yang tidak halus (berlubang/bergerigi) dengan bentuk yang tidak beraturan.
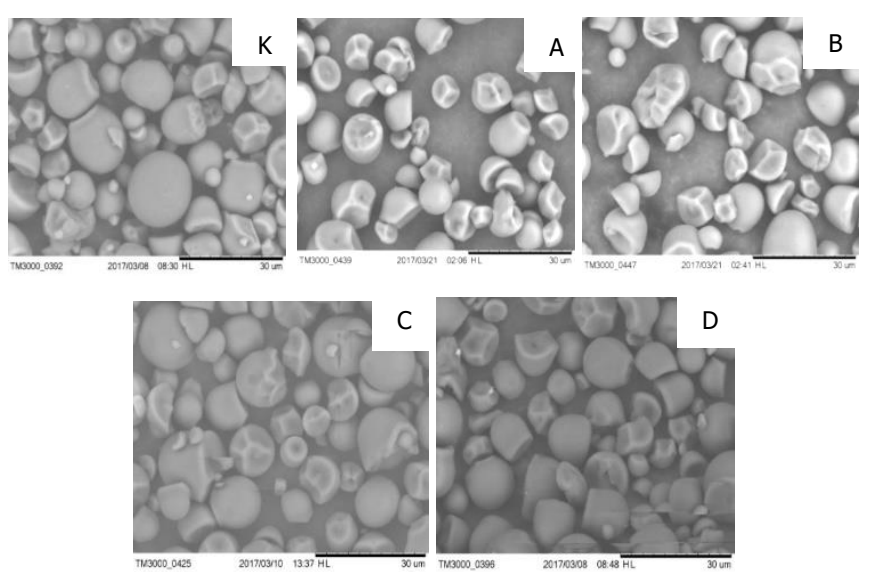

Gambar 5. Makrostruktur pati ubi kayu kontrol (K) dan pati ubi kayu terfermentasi selama 72 jam oleh $C$. guilliermondii $(A)$, T. mucoides (B), S. fibuligera(C), dan C. tropicalis (D)

Granula pati ubi kayu terfermentasi memiliki bentuk bulat kecil tidak beraturan dengan ukuran $5 \mu \mathrm{m}-15 \mu \mathrm{m}$. Bentuk yang demikian mengindikasikan granula terliberasi selama fermentasi. Wahyuni dkk. (2017) melaporkan bahwa granula pati ubi kayu terfermentasi tergolong tipe A yang ditandai dengan karakteristik puncak yang tajam dengan tingkat kristalinitas $25,68 \%$ $20 \%$. Nurhayati dkk. (2014) melaporkan bahwa tingkat kristalinitas juga menggambarkan tipe granula, seperti pada granula pati pisang yang memiliki kristalinitas $18,74-20,08 \%$ dengan granula pati tipe C. Akan tetapi untuk penentuannya tipe granula pati secara detail 


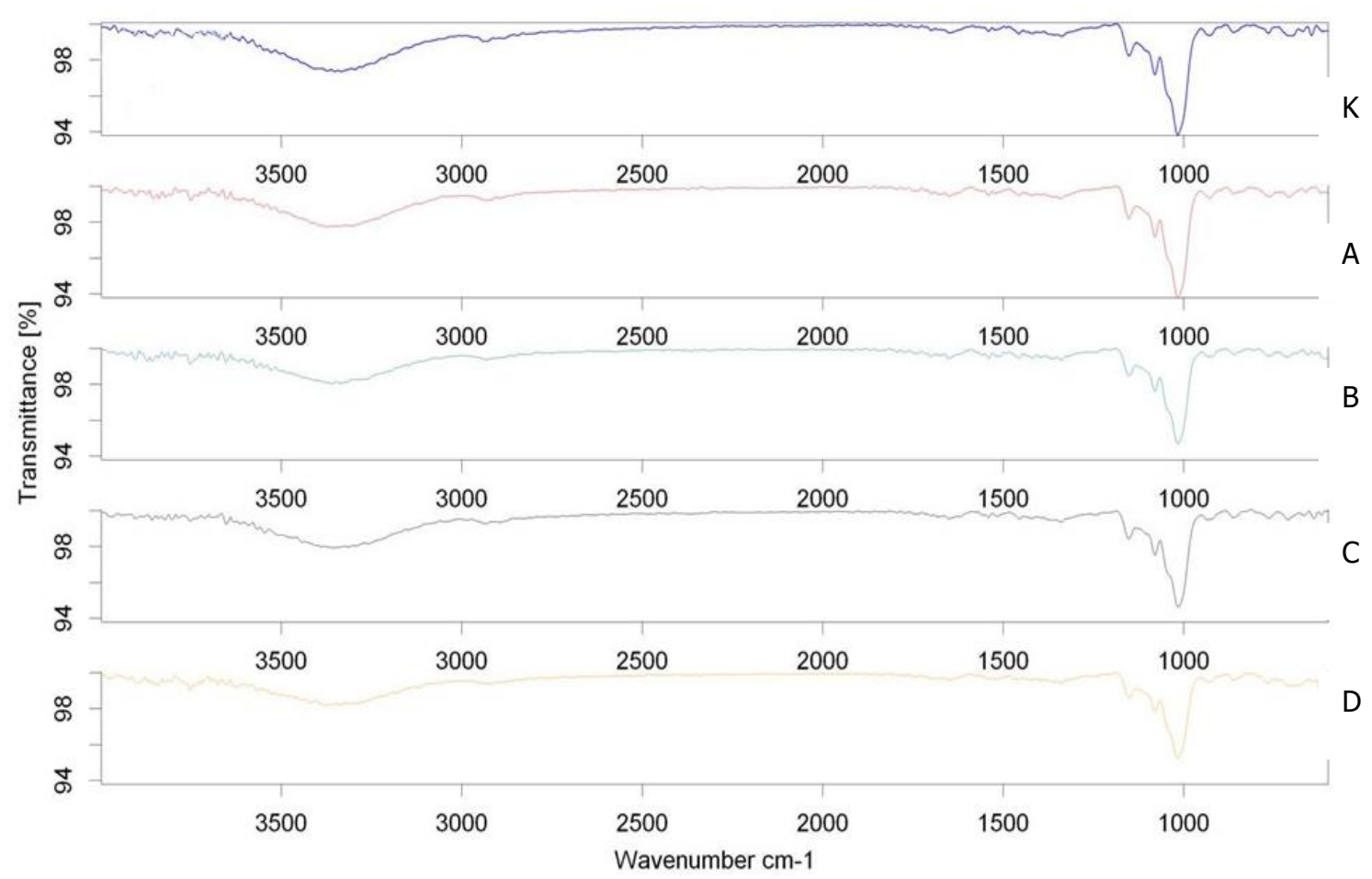

Gambar 6. Spektra pati ubi kayu kontrol (K, dan pati ubi kayu terfermentasi selama 72 jam oleh (A) C. guilliermondii, (B) T. mucoides, (C) S. fibuligera, dan (D) C. tropicalis

harus ditentukan dengan analisis menggunakan alat XRD (X Ray Difraction).

Menurut Zhu (2015) granula pati ubi kayu ukurannya berkisar $2 \mu \mathrm{m}-32 \mu \mathrm{m}$. Granula pati ubi kayu dalam aplikasinya pada pembuatan roti berhubungan dengan struktur roti. Diduga granula pati yang berkelompok akan melemahkan performa mengembangnya roti. Pati ubi kayu terfermentasi menghasilkan $20 \%$ perubahan pada bagian permukaan granula pati (Alonso dkk., 2016).

Hasil pengamatan SEM menunjukkan granula pati ubi kayu terfermentasi memiliki permukaan tidak rata dengan gerigi/lubang yang dangkal berdiameter cukup besar. Hal ini diduga akibat terhidrolisis oleh amilase maupun asam organik. Asam memiliki peran dalam perubahan granula pati. Seperti yang dilaporkan Garcia dkk. (2016) bahwa pati ubi kayu dengan keasaman $4,92 \%$ bisa berperan pada pengikisan dipermukaan granula pati, dan kristalinitas menjadi rendah dengan entalpi yang lebih rendah pula.

\section{Gugus Fungsi Pati Ubi Kayu Terfermentasi}

Dengan semakin lama waktu fermentasi mengindikasikan perubahan yang lebih nyata baik nilai populasi khamir maupun $\mathrm{pH}$. Pengaruh fermentasi yang cukup signifikan menjadi alasan untuk dilakukannya analisis gugus fungsi pati dengan alat FTIR. Profil gugus fungsi pati ubi kayu terfermentasi khamir indigenus tapai dianalisis pada pati yang terfermentasi 72 jam (Gambar 6). Hal ini karena pati yang memiliki nilai $\mathrm{pH}$ paling rendah yang mengindikasikan perubahan yang lebih dibanding pati alami (Garcia dkk., 2016) maupun yang terfermentasi kurang dari 72 jam (Jayus dkk., 2016).
Gambar 6 menunjukkan spektra FTIR pati ubi kayu terfermentasi 72 jam. Fermetasi pati ubi kayu memiliki spektra penyerapan pada puncak $3291,2 \mathrm{~cm}^{-1}$ melebar mengindikasikan getaran gugus ikatan $\mathrm{O}-\mathrm{H}$, puncak $2920 \mathrm{~cm}^{-1}$ mengindikasikan getaran gugus $\mathrm{C}-\mathrm{H}$ streching. Spektra penyerapan puncak $1630 \mathrm{~cm}^{-1}$ mengindikasikan adanya air dan $1149 \mathrm{~cm}^{-1}$ ditandai sebagai $\mathrm{C}-\mathrm{O}-\mathrm{C}$ jembatan ulur asimetrik spektra penyerapan $1016 \mathrm{~cm}^{-1}$ ditandai sebagai sifat struktrur relatif amorphous gel pati (Chen dkk., 2017; Wahyuni dkk., 2017). Pada pati ikatan silang spektra penyerapan sekitar 1300-1500 $\mathrm{cm}^{-1}$, karakteristik yang diyakini membentuk ikatan phosporus oksigen $(P=0)$, sedangkan karakteristik tiga serapan lainnya $1157 \mathrm{~cm}^{-1}$, $1082 \mathrm{~cm}^{-1}$, dan $1016 \mathrm{~cm}^{-1}$ menunjukkan adanya ikatan karbon oksigen (-CO) diikatan silang pati.

\section{KESIMPULAN}

Khamir indigenus tapai mampu tumbuh selama fermentasi pati ubi kayu hingga meningkat sekitar 2 siklus $\log _{10} \mathrm{CFU} / \mathrm{ml}$. Sifat-sifat fisikokimia pati ubi kayu terfermentasi oleh khamir indigenus tapai (Candida guilliermondii, Trichosporon mucoides, Saccharomycopsis fibuligera, dan Candida tropicalis) yaitu memiliki kadar amilosa berkisar antara $11,28 \%$ $15,61 \%$, viskositas puncak $4331 \mathrm{cP}-4918 \mathrm{cP}$, viskositas breakdown 1831 cP-2072 cP, suhu awal gelatinisasi $68,40{ }^{\circ} \mathrm{C}$, viskositas akhir $2914 \mathrm{CP}$, viskositas setback $833 \mathrm{cP}$, waktu puncak 5,53 menit, sifat termal meliputi nilai To $64,7{ }^{\circ} \mathrm{C}-67^{\circ} \mathrm{C}$, Tp $69,1{ }^{\circ} \mathrm{C}-71,2{ }^{\circ} \mathrm{C}$, Tc $73,9^{\circ} \mathrm{C}$ -

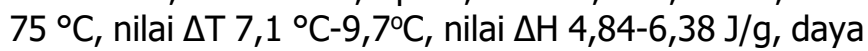
kembang $8,4 \mathrm{~g} / \mathrm{g}-10,4 \mathrm{~g} / \mathrm{g}$ pada $75^{\circ} \mathrm{C}$. Pati ubi kayu 
terfermentasi memiliki spektra puncak FTIR 3291,2 cm-1 (gugus ikatan O-H), puncak $2920 \mathrm{~cm}^{-1}$ (gugus ikatan $\mathrm{C}-\mathrm{H}$ ), puncak $1630 \mathrm{~cm}^{-1}$ (kandungan air), $1149 \mathrm{~cm}^{-1}$ (ikatan CO-Culur asimetrik), puncak $1016 \mathrm{~cm}^{-1}$ (sis amorphous).

\section{UCAPAN TERIMA KASIH}

Ucapan terima kasih disampaikan kepada Kemristek Dikti yang telah mendanai penelitian ini melalui Program Penelitian Strategis Nasional 2016/2017 No 0512/UN25.3.1/LT/2017. Terima kasih juga disampaikan kepada Putu Frida Oktaningtias W., Ssi. yang telah membantu operasional DSC, dan RVA di Laboratorium Center for Development and Advanced Science and Technology (CDAST) Universitas Jember.

\section{DAFTAR PUSTAKA}

Alonso-Gomez, L., Nino-Lopez, A. M., Romero-Garzon, A. M., Pineda-Gomez, P., del Real-Lopez, A., dan Rodrigues-Garcia, M. E. (2016). Physicochemical transformation of cassava starch during fermentation for production of sour starch in Columbia. Starch-Starke 68: 1139-1147.

AOAC (1995). Official methods of Analysis of The Association Analytical Chemists (AOAC). Dipublikasi oleh: TheAssociation of Official Analytical Chemist. Washington DC, USA.

Angeloni, M. M. J., Kurtz, D. J., Raguzzoni, J. C., Delgadillo, I., Maraschin, M., Soldi, V., Reginatto, V., dan Amante, E. R. (2009). Expansion properties of sour cassava starch (Polvilho Azedo): variable related to its practical application in bakery. Starch-Starke 61 (12): 716-726.

Armanto, R., dan Nurasih, A. S. (2008). Kajian konsentrasi bakteri asam laktat dan lama fermentasi pada pembuatan tepung pati singkong asam. Agritech 28 (3): 97-101.

Chen, B., Dang, L., Zhang, X., Fang, W., Hou, M., Liu, T., dan Wang, Z. (2017). Physicochemical properties and microstructural characteristic in starch from kudzu root as affected by cross-linking. Food Chemistry 219 (1): 93-101.

Chinsamran, K., Piyachomkwan, K., dan Santisopasri, V. (2005). Effect of lactic acid fermentation on physico-chemical properties of starch derived from cassava, sweet potato and rice. Kasetsart J39 (9): 76-2005.

Copeland, L., Blazek, J., Salman, H., dan Tang, M. C. (2009). Food hydrocolloids form and functionally of starch. Food hydrocolloids 23 (6): 1527-1534.

De, S. A. C. M., Azevedo, M. S., Ribeiro, D. H. B., Costa, A. C. O., dan Amante, E. R. (2014). Validation of HPLC and CE methods for determination of organic acids in sour cassava starch wastewater. Food Chemistry 172 (1): 725-730.

Dura, A., Blaszczak, W., dan Rosell, C. M. (2014). Functionality of porous starch obtained by amylase or amyglucosidase treatments. Carbohydrate polymers 101 (1): 837-845.

El-Sharoud, W. M., Belloch, C., Peris, D., dan Querol, A. (2009). Molecular identification of yeasts associated with traditional egyptian dairy products. Journal of Food Science 74 (7): 16.

Freire, A. L., Ramos, C. L., dan Schwan, R. F. (2015). Microbiological and chemical parameters during cassava based-substrate fermentation using potential starter cultures of lactic acid bacteria and yeast. Food Research International 76: 787-795.

Garcia, M. C., Franco, C. M. L., Junior, M. S. S., dan Caliari, M. (2016). Structural charateristics and gelatinization properties of sour cassava starch. Journal of Thermal Analysis and Calorimetry 123 (2): 919-926.

Gunawan, S., Widjaja, T., Zullaikah, S., Ernawati, L., Istianah, N., Aparamarta, H. W., dan Prasetyo, D. (2015). Effect of fermenting cassava with Lactobacillus plantarum, Saccharomyces cereviseae, and Rhizopus oryzae on the chemical composition of their flour. International Food Research Journal 22 (3): 1280-1287.

Jayus, Nurhayati, N., Subagio, A., dan Widyatmoko, H. (2016). Modifikasi pati ubi kayu secara fermentasi dengan Lactobacillus manihotivorans dan L. fermentum yang diisolasi dari gatot. Prosiding Seminar Nasional BALITKABI Tahun Anggaran 2016.

Jimoh, S. O., Ado, S. A., Ameh, J. B., Whong, C. M. Z., dan Anglais, A. T. E. (2012). Charateristics and diversity of yeast in locally fermented beverages sold in Nigeria. World of Engineering and Pure and Applied Sci 2 (2): 40-44.

Katekhong, W., dan Charoenrein, S. (2012). Effect of rice storage on pasting properties, swelling and granular morphology of rice flour. Asian Journal of Food and AgroIndustry, 5 (4), 315-321.

Kustyawati, M. E., Sari, M., dan Haryati, T. (2013). Efek fermentasi dengan Saccharomyces cereviseae terhadap karakteristik biokimia tapioka. Agritech 33(3): 281-287.

Maribel, O. M., Senay, S., Orhan, D., dan Kadir, G. G. U. G. (2014). Physicochemical properties of starch from a cerealbased fermented food (Tarhana). Journal of Nutrition \& Food Sciences 4 (3): 2-7.

Nurhayati, N., Jenie, B. S. L., Widowati, S., dan Kusumaningrum, H. D. (2014). Komposisi Kimia dan Kristalinitas Tepung Pisang Termodifikasi Secara Fermentasi Spontan dan Siklus Pemanasan BertekananPendinginan. Agritech, 34 (2), 146-150.

Ogunnaike, A. M., Adepoju, P. A., Longe, A. O., Elemo, G. N., dan Oke, O. V. (2015) Effects of submerged and anaerobic fermentations on cassava flour (Lafun). African Journal of Biotechnology 14 (11): 961-970.

Oslan, S. N., Salleh, A. B., Noor, R., Raja, Z., Rahman, A., Leow, A., dan Chor, T. (2012). Locally isolated yeast from Malaysia: Identification, phylogenetic study and characterization. ACTA BiochemicaPolonica 59 (2): 225229.

Qi, Y., Cui, T., Jing, Y., Shan, C., Zhao, Z., Wu, P., dan Zhang, X. (2015). Comparative studies between physicochemical properties of white waxy wheat flour and glutionous rice flour. OALib 2 (6): 1-8.

Rahmiati, T. M., Purwanto, Y. A., Budijanto, S., dan Khumaida, N. (2016). Sifat fisikokimia tepung dari 10 genotipe ubi kayu (Manihot esculenta Crantz) hasil pemuliaan. Agritech 36 (4): 459-466.

Schwan, R. F., Almeida, E. G., Souza-dias, M. A. G., dan Jespersen, L. (2007). Yeast diversity in rice-cassava fermentations produced by the indigenous Tapirape people of Brazil. FEMS Yeast Research 7 (1): 966-972.

Subagio, A. (2013). Keunggulan mocaf sebagai bahan baku snack. Foodreview Indonesia 8 (10): 38-40.

Tamang, J. P., Shin, D., Jung, S., dan Chae, S. (2016). Functional properties of microorganisms in fermented foods. Frontiers in Microbiology 7 (4): 1-13.

Wahyuni, S., Ansharullah, Saefuddin, Holilah., dan Asranudin. (2017). Physico-chemical properties of Wikau maombo flour from cassava (Manihot esculenta Crantz). Journal of Food Measurement and Characterization 11 (1): 329-336. 
Wang, S., dan Copeland, L. (2013). Molecular disassembly of starch granules during gelatinization and its effect on starch digestibility: a review. Foood \& Function 4 (1).

Yuliana, Nety N. S., Sugiharto, R., dan Amhety, D. (2014). Effect of spontaneous lactic acid fermentation on physico-chemical properties of sweet potato flour. Microbiology Indonesia $\mathbf{8}$ (1): $1-8$.

Zavareze, E. da R., Storck, C. R., de Castro, L. A. S., Schrirmer, M. A., dan Dias, A. R. G. (2010). Effect of heat moisture treatment on rice starch of varying amylose content. Food Chemistry 121 (2): 358-365.

Zeng, F., Ma, F., Kong, F., Gao, Q., dan Yu, S. (2015). Physicochemical properties and digestibility of hydrothermally treated waxy rice starch. Food Chemistry 172 (1).

Zhu, F. (2015). Composition, structure, physicochemical properties, and modifications of cassava starch. Carbohydrate polymers. 122: 456-480. 